\title{
Oil well casing cement flash setting problem causes and identification strategy based on cheese model
}

\author{
Abdeslem Leksir ${ }^{1}$ \\ Received: 26 January 2020 / Accepted: 7 April 2020 / Published online: 28 April 2020 \\ (c) The Author(s) 2020
}

\begin{abstract}
This paper deals with oil well cementing flash setting problem definition, interpretation and localization via PABM (phenomenon analysis-based method) and Swiss cheese model investigation. Cementing is the most critical job throughout the well realization process; it presents the face of the well during production or abandonment. Within cement job some, problems come out and could lead to lose the well objectives, and it can be classified as cementing program's awkward or operational hitches. This work is oriented toward operational stage, even if cement program and preparation seem in the rules of the art, the execution stage can interrupt the smooth running of cement job. Flash setting is one of the most critical problems that could be occurred, and it can be recognized by the prior increases in pressure to reach unpumpable stage. Identifying flash setting phenomenon and distinguishing them from other operational comportment stay hard task and present the heart of this work. Consequences could be varied from simple cement left inside casing to total free pipe of the annulus. PABM together with cheese model is proposed to be used for deep analysis of flash setting problems and points out the real causes, if they exist, rather than flash setting. The method proposed includes five steps, description of the operation, phenomenon, assumptions, cheese model and conclusion. The three first steps construct operation scrutiny, and the fourth step represents PABM. In this latter method, assumptions will pass through a selective process made from operation facts, and only the adequate assumption reaches the last layer of the model. Practical cases have been detailed to point out the merit of this method and distinguishing flash setting from other related cement problems.
\end{abstract}

Keywords Well integrity $\cdot$ Cement flesh setting $\cdot$ Problem investigation $\cdot$ Swiss cheese model

\section{Introduction}

Well cementing quality represents the support for further drilling and represents the most critical indicator for oil and gas well's production lifetime. Divers definitions have been presented in the studies to describe cement flash setting (Javed 1987). Unlike false setting when intensive mixing may restore the situation, flash setting is a rapid development of gel in freshly mixed cement and there is no way to recover the situation (Choudhary et al. 2015). Chemically, if the appropriate amount of gypsum did not provide to the cement mixture, hydration phenomenon reacts rapidly (Javed 1987). Consequently, temperature increases excessively induce an irreversible compressive strength

Abdeslem Leksir

leksir1@yahoo.fr

1 SONATRACH, University of Annaba, Annaba, Algeria development (Gauffinet-Garrault 2012). This challenging is related to the cement nature together with their additives interaction, which make them related to material nature rather than operational stage.

This work deals with practical cases to point out the influences of the way of cement job executed on the overall cement quality. Cement job is the operation of pumping cement inside casing and through annular to seal all geological formation, in order to do further drilling, start production or abandonment (Charles and Greg 1973). The way of execution represents challenges to oil well cementing companies (Eduardo et al. 2004), passing from conventional strict execution method, cement modeling and design (Bittleston et al. 2002; Guangping et al. 1999) to real-time system (Abdullah et al. 2019) and expert system (Guangping et al. 1999). Moreover, the number of non-conventional wells drilled, as HPHT (high pressure, high temperature) (Amin et al. 2017), geothermal wells (Thomas et al. 2012) and ERD (extended reach drilling) (Navas et al. 2016) is

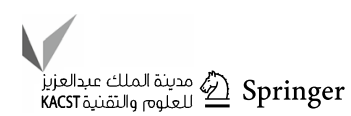


rising rapidly, which makes cement execution part facing new and complex challenges.

Contrary to cement nature behavior, operational stage is oriented toward crew and equipment, in Reason (1990). Reason introduces new HSE method dealing with human error analysis to avoid accidents. In this proposition, each layer of cheese represents a level of protection for the system, while each hole represents weak in defensive system. Finally, any undesirable action will be filtrated and eliminated by selfprotective constructed by cheese layers, if this protection system is weak and an action could jump over them, and then, accident takes place (Altabbakh and Murray 2011). This assumption was updated by Dekker (2002) to be able to overcome other working environment influences in addition to human error.

We inspired this idea of Swiss cheese model and reformed them to fulfill our objective. Different from accident protection, investigation takes the inverse itinerary; when incident occurs, an examination of all events starts to point out the real causes. Layers are formed from facts, only the hole in the cheese represents the adequate itinerary, and any attempt to pass elsewhere in the layer rather than the hole will face a contradiction.

In this work, incidents' investigation is the operation of examining the execution part to point out the real causes, including all incident notification and reporting flowchart (Hanooman 2008). Cement job execution part of investigation has some specifications that should be taken into count, begin from chemical and mechanical properties (Thomas et al. 2012), pass through fluid way of placement (Charles and Greg 1973), (Smith and Ravi 1991), and testing apparatus which are improved periodically (Zichang et al. 2018), and end by evaluation analysis (Griffith et al. 1992). PABM goes deeper in incident analysis, unlike conventional ones, which deals with the direct causes to achieve the acceptable problem's reason. PABM Search for similar causes that can lead to the same results; this later thoroughly looks for any contradiction or argument that redirects the investigation. The results of PABM represent the input of cheese model, and phenomena will be converted to assumptions because each of them comes from a way of thinking or point of view toward the problem. The layers of cheese model are made from facts of the problem, and elimination of assumptions will be based on contradiction faced any layer (fact). At the end of this selection, only the adequate reason (assumption) will pass through all layers without any contradiction, and then, PABM cheese model objective is achieved.

While working in engineering department, we recognize that all our investigations are more or less oriented, or let say with objective predefined. As an example, if we have pressure rise during cement pumping or displacement, investigations are oriented toward flash setting problem straightly. This comes from the easy way that problems are treated. In reality, all drilling operations are complex and difficult to interpret separately from the influences of other nearby operations. The question we asked is: How we can deal as easy as this way with complicated drilling operations? We search many times, in the literature, to get answer to this question without success. In order to get a response to the question, we implant this method, and it is a combination between a spiritual part phenomenon and assumptions on the one hand, and technical/logical part on the other hand.

In this paper, a new method is proposed to analyze flash setting and differentiate them from other cementing-related problems. The main aim is the analysis technique; based on brainstorming method, phenomena and assumptions will be achieved. The acceptable cause (assumption) will be gained through a system of selection layers made from real operation facts. In addition, key of performance indicator is proposed to evaluate cementing operations, taking into consideration the integrity of the well. The paper is organized as: A general view of the well integrity and barriers is presented in the second section. A general presentation of flash setting problem and causes together with operation performance is detailed in section three. Fourth section presents investigation methodology and cases studies specifications. Conclusion is presented at the end of the paper.

Well integrity management system

Integrity of the well is the main objective throughout all well life; generally, it is related to obstacle that could be built to prevent formation fluids from leaking inside the hole and migrate to the surface (Catalin and Opeyemi 2019). Twobarrier philosophy is the main technique used during drilling operations execution, and seal is offered by drilling fluids, cement or mechanical elements as packers.

Commonly, integrity management system focuses on two main systems of barriers described below:

- Short-term system Means barriers that will prevent downhole fluids comes out of surface during specific period of time.

- Long-term system Means barriers that will prevent downhole fluids comes out of surface permanently.

This later is in term of system duration; another point of view oriented to operational part is presented below:

- Principal operations Operations which could not be done in hidden time.

- Secondary operation Operations which could be done parallel to other operations.

Drilling operations and mechanisms are typically presented in the Table 1:

It can be clearly seen that casing cement operation is the unique system that satisfies all requirements either in terms of time or operation. Cement operation and system is a vast 
subject; in this work, we will be oriented toward cement problems investigation and spatially flash setting.

\section{Cement flash setting problem}

In order to point out the serious problem that could be generated by a cement flash setting, Fig. 1 presents time consumption for drilling $9 " 5 / 8$ section compared to the hole well duration regarding three adjacent wells drilled in the same area and in the same conditions. One can see that in the two wells: Well 1 and Well 2, section 9" 5/8 represents only $16 \%$ out of the hole time consumed while drilling the well. Conversely in Well 3 where cement flash setting takes place, 9" $5 / 8$ section consumes $60 \%$ of the hole realization time.

In order to point out the influences that could be engendered by changes in retarder concentration (Ikpeka et al. 2019), Fig. 2 presents two thinking time concerning the same slurry design with variation in retarder concentrations-A with $3.5 \mathrm{k} / \mathrm{T}$ and-B $3 \mathrm{k} / \mathrm{T}$. One can see that even if all parameters regarding slurry design and down-hole specifications are similar, thickening time at $40 \mathrm{BC}$ reduces from $16 \mathrm{~h} 8 \mathrm{~min}$ to $11 \mathrm{~h} 6 \mathrm{~min}$.

Figure $3 \mathrm{a}$ and $\mathrm{b}$ represents simulated temperature used and elaborates cement program, while Fig. $3 c$ represents the real logged temperature. One can see that; the overall behavior of simulated temperature could be similar to the real one as in Well 2; or the allure of logged temperature

WELL1

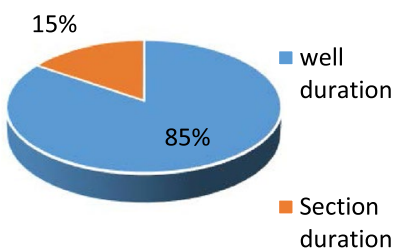

(A) Wells realized without problem

\section{WELL3}

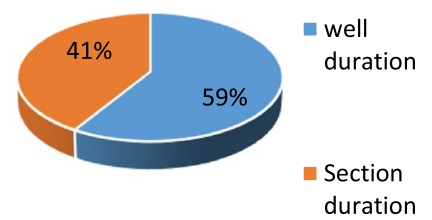

(B) Well realized with presence of cement flash setting

Fig. 1 9" 5/8 section consumption time compared to hole well realization time will receive some changes as in Well 1 and Well 3. To avoid cement incidents, in addition to crew training Appendix A, three types of actions should be taken, pre-job preparations, during cementing critical decision and post-job recommendations and lesson learned, to prevent the occurrence of the same problem in the future wells.

Pre-cement job failure factor Pre-cement failure factor (PCFF) deals with major difficulties which could be recognized before cementing, and these problems are presented in Appendix B. The apparition of any problem means that there is a problem which threatens.

During cement job failure indicators factors Different from post- and pre-job action, while job running, if undesirable phenomenon takes place, decision is critical in terms of time and influences. The precise information represents the foundation for accurate analysis, the table provides factors that could help to achieve a good decision. The main aim at this step is to push cement down hole, in order to cover the open hole and fulfill the section requirement, as shown in Appendix C.

Post-job recommendations and lesson learned at the end of cement job two essential operations should be done, pressure test and cement evaluation operation, as shown in Appendix D. Some precautions should be taken in order to continue drilling operations safely which are detailed in Appendix E.

KPI (key of performance indicator) sheet in order to evaluate the hole cement job, a KPI sheet is elaborated and proposed in Appendix F. KPI sheet is divided into three parts. The first part, zero KPI factor, takes into account the major incidents that will engender the loose of cement objectives. The second part, principal KPI, gives an overview of ordinary cement job execution. The third part, secondary KPI, points out more details about cement operations.

In this work, a KPI factor is proposed to quantify the quality of cement job,

$\delta_{\mathrm{KPI}}=\mathrm{ZKPI} \frac{(2 \mathrm{PKPI}+\mathrm{SKPI})}{300}$

where $\delta_{\mathrm{KPI}}$ is KPI factor; ZKPI, zero KPI factor; PKPI, principal KPI factor; SKPI, secondary KPI factor.

It can be clearly seen that if ZKPI is equal to zero, KPI factor will be valueless.

\section{Investigation based on cheese model}

Unlike the majority of analysis based on the habitual operations, cheese model method takes the current job as reference and searches nearby for any other phenomenon that can direct the final decision toward a new result. Following is the details of cheese model method:

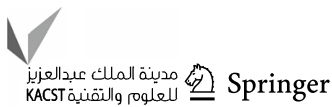




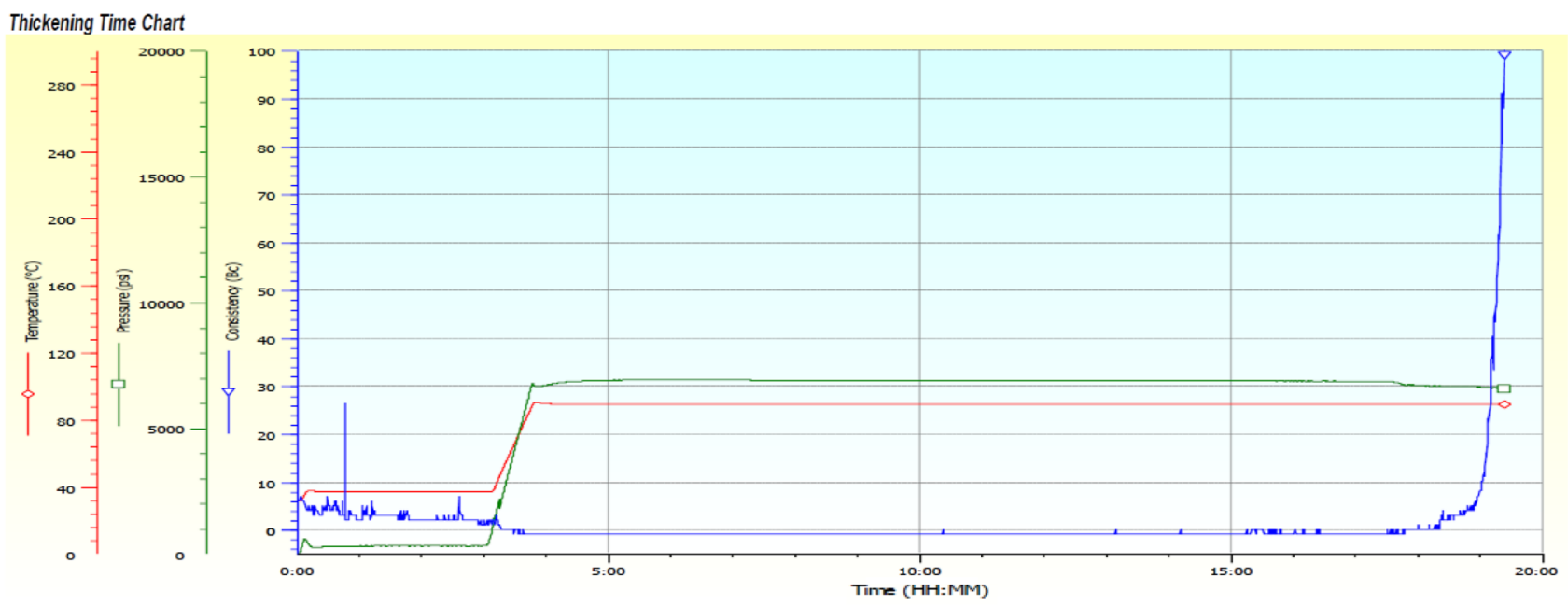

(A) Slurry thickening time with $3.5 \mathrm{k} / \mathrm{T}$ retarder concentration.

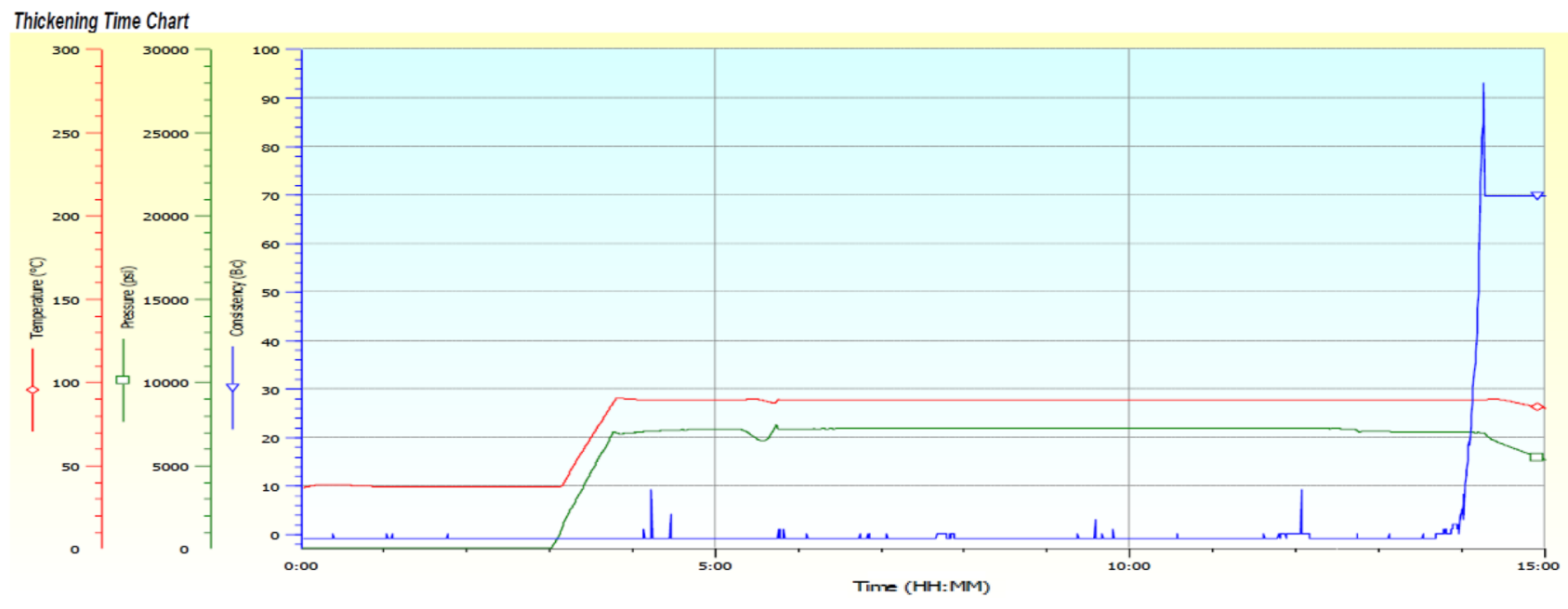

(B) Slurry thickening time with $3 \mathrm{k} / \mathrm{T}$ retarder concentration.

Fig. 2 Influences of variation in slurry retarder concentrations on the thickening time

Cheese model is run in five steps:

\section{Step 1}

Operation description In this section, a detailed presentation of the hole cement job operations, together with all specifications, and proves (charts), related to the operation, should be presented.

Conventional analysis Based on operation examination (root causes, fact-finding information gathered, etc.), a comparison between the current job specifications with the previous similar job and/or well-known standards, any undesirable specification should be taken into account to pinpoint straightly to the result. The inconvenience of this analysis is the numerous results obtained, which makes the situation doubted and decision making becoming hard task.

\section{Step 2}

Phenomenon Deeper than the previous section, this stage focuses on the profounder causes, which could be took place at the same time and does not appear in the previous section, which can lead to the same results. Generally, based on precedent results, some phenomena will be extracted, to give an overall view of the problem.

\section{Step 3}

In this section, the previous phenomena resulted from the precedent section represent the input, and each input will be treated and examined to form at least one assumption. An assumption is a point of view, based on one or more 


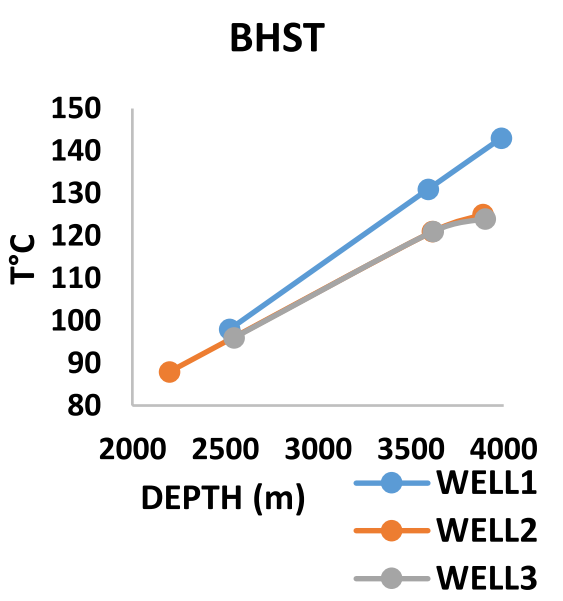

(A) BHST

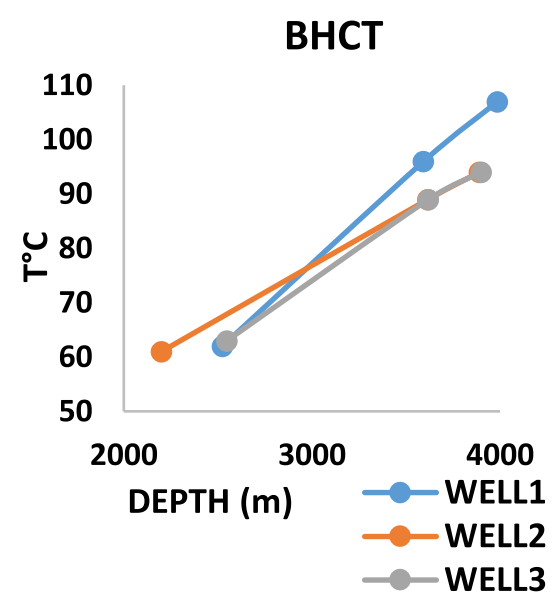

(B) BHCT

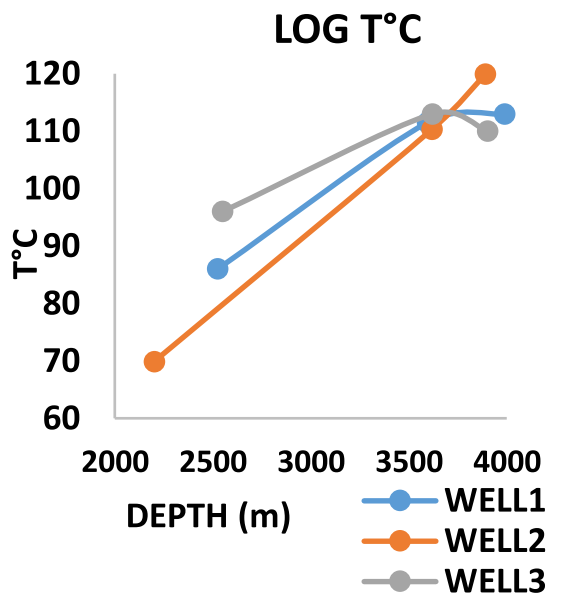

(C) $\operatorname{LOG~T}{ }^{\circ} \mathrm{C}$

Fig. 3 Influences of down-hole temperature variation

phenomena, regarding the problem. The outcome of this section is a collection of assumptions which are generally accepted.

\section{Step 4}

Assumptions resulted from the previous section will be passed through selecting layers of cheese model. Those layers represent the facts of each specific cementing operation as shown in Fig. 4. Any assumption come across contradiction with any layer (fact) of cheese model will be automatically eliminated. This section ends by one assumption which is technically accepted and fulfills all cheese model system conditions.

\section{Step 5}

Finally, the original cause is found and phenomenon is clearly described. Lesson learned is taken and describes the precautions that should be made, in order to avoid the apparition of the same problem in the future.

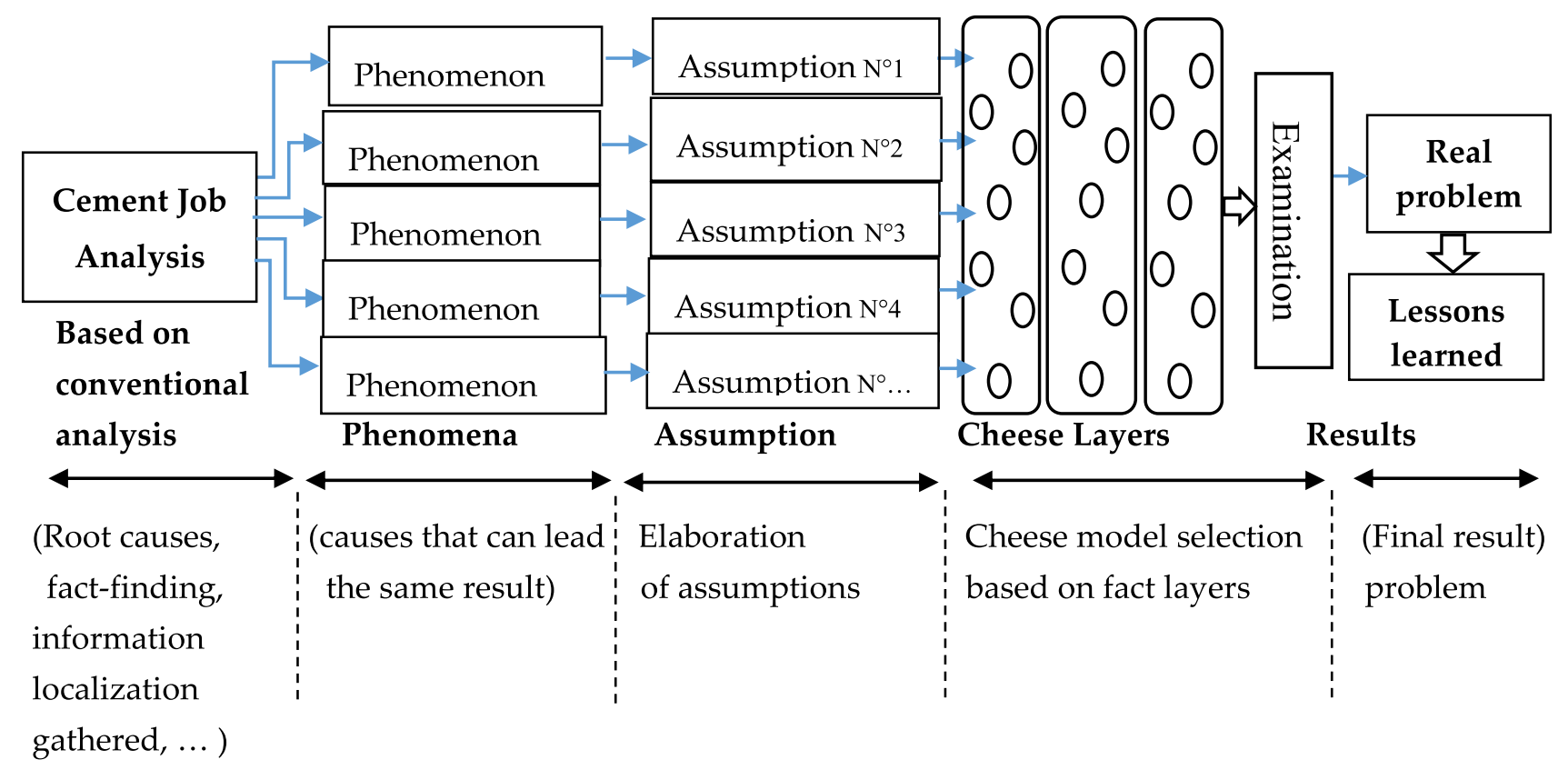

Fig. 4 PABM and cheese model process presentation 
Figure 4 presents the cheese model, where analysis of problem passes from operation description and failure analysis, to examine similar causes that can lead to the same results. The application of cheese model can facilitate the investigation operation running and lead to more accurate decision. Following are some cases studies where cementing job interrupted by flash setting problem.

\section{First case}

This concerns the problem taking place in Well 4 while cementing 13 3/8" CSG column, and all cement operation seems to be good, till the rise of pressure during displacement to reach 3000 psi (Pump $56 \mathrm{~m}^{3}$ of displacement fluid out of $92.6 \mathrm{~m}^{3}$ ). An investigation has been initiated leading to the real cause, which can be concluded that the supervisor assuming the $\mathrm{KCl}$ is $50 \mathrm{~kg}$ per sack, but in reality, it was $25 \mathrm{~kg}$ per sack. Representing the undesirable rise of pressure during displacement stage, it can be clearly seen that the pressure behavior of flash set is really far from sudden reaction or bump, not similar to casing cement bump recognized routinely at the end of displacement. This comportment will be the reference for all other cases analysis.

In this case, all intermediate section will be passed because the initial phenomenon become a fact (wrong quantity of additive). Amelioration action could be rechecking the logistic of the company and elaborate an adequate training for the crew Appendices A, B.

\section{Second case}

Step 1 Generally, all (well 5) $4 \frac{1}{2} 2$ liner cementing operations are in the right way. Liner cements job description: Pump $8 \mathrm{~m}^{3}$ of spacer@1.65 sg and $4.63 \mathrm{~m}^{3}$ slurry@ 1.90 sg, drop dart plug followed by $1.6 \mathrm{~m}^{3}$ freshwater and 23.21 mud @ $1.44 \mathrm{sg}$. At the end of displacement liner was tested @ 3500 psi, no return after bleed-off. An overpull of around $20 \mathrm{~T}$ was recorded when pulling setting tool upward to circulate at top of liner.

Step 2 Phenomena that could be probably lead to this problem of string stacking are:

1 , pressure rise; 2 , down-hole stuck; 3 , mechanical problem; 4, down-hole formation failure; 5 , down-hole tool failure.

Step 3 Assumptions:

1. Flash setting due to inadequate cement mixing, wrong down hole $\mathrm{T}^{\circ}$ or other operational failures.

2. False setting due to additive mixing system.

3. Mechanical problem due to object falling in hole or casing collapse.
4. Down-hole formation restriction due to interaction between formation and cementing fluids.

5. Down-hole tool failure due to system failure, lack of preparation or crew non-qualified.

Step 4 Cheese model layers (Facts).

Layer 1: Setting tool and top liner are all located inside the previous casing.

Layer 2: Cementing operations are executed in the rules of the art.

Layer 3: Packer setting operations run normally, and tiny rotation of the string registered without any torque generation.

Layer 4: Pressure rises suddenly from 500 to 3500 psi in around $3 \mathrm{~min}$.

Layer 5: Setting tool string was stacked (cannot be pulled out of the hole).

\section{Examination of assumptions}

The first assumption passes through the first layer without any remarkable problem, because there is not a direct relation with the position of the objective system (inside or outside casing) and flash-setting occurrence. The second layer confirms that there is no mixing difficulty, which faces a contradiction with the first assumption. The first assumption faces a contradiction also with the third and the fourth layers. If flash setting takes place, packer setting and rotation are impossible, and pressure curve is sudden not progressive. Then, the first assumption is eliminated.

The second assumption passes through the first layer because there is no real relation between mixing system and setting tool system position (inside or outside). On the other hand, the second assumption faces a contradiction with the layer two, four and five. If false setting takes place, a trouble while cement pumping and displacement will surely encounter. In addition, pressure will not rise suddenly as it is declared, and finally, this assumption cannot lead to only upward stack of the string. Then, the second assumption is eliminated.

The third assumption faces a contradiction with layer one, three and four. All equipment (setting tool and top liner) where located inside the previous casing, and it is far from the reality to be collapsed. (Drill string and casing are run without any remarkable problem.) If object was fall inside, there is no way to set packer or rotate the string freely. The pressure also points out that the circulation itinerary was totally blocked, in case of object falling mechanical system will be affected (pull out, run in hole and rotation) and hydraulic circulation will be slightly affected (pressure marginally increase). The second assumption does not 
have direct relation with mixing operation. Then, the third assumption is eliminated.

The fourth assumption faces contradiction with the first layer. The location of problem (setting tool) is totally inside the previous casing, and there is no way to have contact with geological formation. Then, the fourth assumption is eliminated.

If the fifth assumption is true, there is not any contradiction with layers one, two, four and five because operation execution, location, pressure rise and even stuck of setting tool does not have any relation with setting tool mechanism. This later represents the interaction between setting mechanism and other internal systems. The layers three and five are verified too because setting packer or rotation does not have any relation with pulling setting tool out of their emplacement. Furthermore, setting packer and rotation of string mean the system is free in rotating downward, but does not mean the system is free in rotating upward.

Step 5 Then, the real cause of stacking is down-hole tool failure. Recheck preparation procedure and crew training to overcome these kinds of problems, as shown in Appendices C, D, E.

\section{Third case}

Step 1 13"3/8 Casing (well 6) cement operations run as follows: pump the total volume of lead slurry $84.82 \mathrm{~m}^{3} @ 1.58 \mathrm{sg}$ followed by $5 \mathrm{~m}^{3} @ 1.9 \mathrm{sg}$ of tail slurry, this action takes around four hours. A problem has been encountered while mixing and interrupts the smooth running of the remaining operations; one hour and a half has consumed trying to fix the problem without success. Finally, a decision to continue displacement has been taken, and only $45 \mathrm{~m}^{3}$ was displaced out of $127 \mathrm{~m}^{3}$ programmed to be pumped. Even that, the cement chart presents a sudden behavior of the pressure where pressure rises from 0 to 1500 psi in almost one minute, fixing time together with switching from cement unit to rig pump and free-fall stage will take more than two hours. In addition, while drilling out, cement bottom was found above (FC) float collar. It has been mentioned that there are no arrivals to rig tanks while trying to complete displacement.

Step 2 Phenomena that could be probably lead to this problem of sudden rise of pressure are.

1 , pressure rise by error (wrong reading); 2 , surface system plugged; 3 , down-hole itinerary plugged; 4 , surface valve closed by error; 5 , problem in cement preparation or pumping sequences.

Step 3 Assumptions.

1 , float equipment failure; 2 , object fall in hole; 3 , crew non-qualified, surface equipment that is not ready for the job; 4, flash setting.
Step 4 Cheese model layers (facts).

Layer 1: Cement pumping process was interrupted.

Layer 2: Pumping itinerary is totally isolated from external influences.

Layer 3: Cement bottom was found far from FC.

Layer 4: Pressure rises suddenly.

Layer 5: No arrivals to rig thanks while displacing.

\section{Examination of assumptions}

The first assumption passes through the first, second, fourth and fifth layers without remarkable problems. Practically, there is no real relation between float equipment failure and the process interruption or pumping itinerary. Moreover, sudden rise of pressure confirmed in the fourth layer coincides with habitual float equipment bump of pressure. There is no direct relation between the first assumption and the absence of mud returns, while displacement presented in the fifth layer. The first assumption faces a contradiction with the third layer, while drilling out cement was found far away from FC. Then, the first assumption is eliminated.

The second assumption passes through the first, fourth and fifth layers without problem, because there is not direct relation between surface mixing process and object falling inside hole. Moreover, pressure rise with no returns while displacement coincide with the habitual reaction of mechanical object fall in hole. The second assumption faces a contradiction with layers two and three. No object could fall in hole without opening the circuit, which is not the case, and even the interruption is related to mixing process without opening the circuit; there is no fluctuation in flow rate or pressure rise before the last cubic meters. In addition, the cement was found far from FC, and this could be interpreted that cement was pumped and displaced for time without problem. If the scenario of object falling proposed really takes place, when the object reaches the FC and all pumping attempt will be useless. Then, the second assumption is eliminated.

The third assumption of crew non-qualified passes through the first layer because the process interruption could be due to human error or equipment useless. The third assumption passes through the second and third layers too, because there is no relation between crew or equipment and displacement itinerary or cement bottom position while drilling out. Finally, crew or equipment did not have a direct relation with pressure rise declared in the fourth layer, and this later could be a combination of other parameters as a way of mixing, wrong temperature, additives quality and influences of down-hole conditions, which is not declared in this case. Moreover, the fifth layer confirms that there is a down-hole problem and prevents fluids from flowing freely outside the well during cement displacement, which presents 
a real contradiction with the third assumption. Then, the third assumption is eliminated.

The fourth assumption of flash setting passes through the first layer because while fixing system cement will be in static state, different from pumping state, in these conditions, gels will begin to develop and could reach unpumpable stage. The fourth assumption passes through second, third and fourth layers too, because cement pumping itinerary does not have any relation with flash setting, at the contrary cement found upper than FC is one of the main characteristics of flash setting. In addition, due to waiting time up to two hours, hypothesis of gel development is highly accepted and could reach to unpumpable stage, which leads to flash setting problem. The fourth assumption passes through layer five too, because when flash setting occurs, no displacement of cement is possible.

Step 5 Then, the real cause of pressure rise is flash setting of cement. Crew training to react and take decision at time together with equipment preparation could be the main lessons learned in this case, as shown in Appendix A.

\section{Fourth case}

Step 1 13"3/8 Casing cement job (well 7) has been carried out as follows (cement program): $10 \mathrm{~m}^{3}$ of spacer $@ 1.40 \mathrm{sg}, 83.38 \mathrm{~m}^{3}$ of lead slurry @1.41 sg and $44.49 \mathrm{~m}^{3}$ of tail slurry@1.90 sg has been all mixed and pumped successively. Volume of $190.78 \mathrm{~m}^{3}$ is programmed to be used to push slurry downward in order to seal the open hole section. However, while displacement is of only $101 \mathrm{~m}^{3}$, the pressure rises from 700 to $3000 \mathrm{psi}$ in around $20 \mathrm{mn} .89 \mathrm{~m}^{3}$ of cement left in hole. Deep investigation confirms that while preparing mix water, additives are not added and mixed properly. This assumption was confirmed by laboratory test presented in programmed thickening time test (9 h: $45 \mathrm{~min}$ ) (uses laboratory mix water) and post-job confirmation test ( $1 \mathrm{~h}: 54 \mathrm{~min}$ ) (uses real mix water). It has been mentioned that on the one hand, cement column was found homogeny during drill out and on the other hand, pieces of metal helicoidally shaped were found while drilling out cement.

Step 2 Phenomena that could be probably lead to this problem of pressure rise are:

1, down-hole float equipment failure; 2 , non-adequate mixing leads to cement rock passing through circuit and plugging the course; 3 , non-adequate mixing leads to cement solids separation; 4, non-adequate mixing leads to cement gel developed rapidly; 5 , object fall inside casing and plug of the circuit.

Step 3 Assumptions.

1, Mechanical problem; 2, false setting; 3 , flash setting. Step 4 Cheese model layers (Facts).
Layer 1: Pressure rises progressively.

Layer 2: Cement column homogeny during drill out.

Layer 3: Pieces of helicoidally shape metal found while drill out cement.

Layer 4: No fluctuation in flow rate or pressure while pumping or displacing cement.

\section{Examination of assumptions}

The first assumption passes through the second, third and fourth layers without remarkable problems, because there is no direct relation between mechanical problems and cement column harnesses. Moreover, pieces of metal and no fluctuation of flow rate declared in layers three and four coincide with the general behavior when the mechanical problem occurs. On the other hand, the first assumption faces contradiction with the first layer, because if a mechanical problem takes place, the pressure reacts as bump which is not the case. Even though the pieces of metal declared in the layer three, the reaction of pressure predefined makes this problem in second position. Then, the first assumption is eliminated.

The second assumption passes through the first layer because the phenomenon of false setting needs too much time to take place especially during pumping (movement) slurry. False setting is the separation of solids from the remaining liquids, which takes more time and is a really far from sudden or break phenomenon. False setting faces a real contradiction with the second layer because the cement founded homogeneous while drilling out and at the desired depth. The third layer does not present any relation with false setting. However, the fourth layer presents a real obstacle to this assumption, for the reason that setting means fluid is in transit stage, before separation into two phases fluid part and solid deposit, when surely will appear as variations in fluid flow rate, which is not the case. Then, the second assumption is eliminated.

The third assumption of flash setting passes through the first layer easily, because it represents the real reaction of flash setting, when gel strength developed progressively, the pressure while following the same way. The layer two will be passed easily also because flash setting will not influence the slurry composition and/or strength, and simply it makes gel developments earlier. The third and fourth layers will be passed easily too, because flash setting does not have any relation with object falling in hole, and no fluctuation neither in flow rate nor in pressure is registered while displacement, till the last cubic meters, which represents the real behavior of flash setting.

Step 5 The real cause of pressure rise is flash setting of cement. Crew qualification and good job preparation are the key of success for any job, as shown in Appendices A, B, C 


\section{Fifth case}

Step 1 9" 5/8 Cement job (well 8) was run as follows:

- Circulate before cement job without losses.

- Pump $10 \mathrm{~m}^{3}$ spacer @2.29 sg.

_ Pump 43.44 m $^{3}$ slurry@2.31 sg.

- Displace with $81 \mathrm{~m}^{3}$ with $\mathrm{Q}=400 \mathrm{lpm}$ and $\mathrm{SPP}=600 \mathrm{psi}$. (First bump@89.27 $\mathrm{m}^{3}$ ), pressure increase progressively to reach 1650 psi with full return (steady level).

- Lot of attempts were run to recover the situation, flow rate $2001 \mathrm{pm}$ SPP increase to $2350 \mathrm{psi}$ and then decrease progressively even with very low flow rate. No return even if pumping is still ongoing (Fig. 7) (steady level, estimated down-hole losses $2.5 \mathrm{~m}^{3}$ ). While drilling out, cement is found homogenous, no indication of bridge or drilling parameters perturbation.

Step 2 Phenomena that could be probably lead to this problem of cement left in hole are:

1 , pressure rise due to cement mixing problem; 2 , pressure rise with full return due to pump problem; 3 , pressure begin decreases while pumping is still ongoing due to pump efficiency; 4, lost in hole due to formation restriction.

Step 3 Assumptions.

- Flash setting.

- Mechanical problem (circuit plugged, object fall in hole, pump problem).

- False setting.

- Formation restriction.

Step 4 Cheese model layers (Facts).

Layer 1: Pressure rises progressively.

Layer 2: No return even if pumping is ongoing (at the end of job).

Layer 3: Cement pumped normally, only spacer reaches the open hole (all cement inside casing).

Layer 4: Pressure rise to $2350 \mathrm{psi}$, increasing this value, the pressure will decrease even if pumping is ongoing.

\section{Examination of assumptions}

The first assumption of flash setting passes through the first layer easily because the progressive of the pressure rise is one of their essential characteristics. Flash setting could happen while mixing, pumping or displacement, pumping cement normally does not mean cement is in ordinary conditions, and then, the third layer will be passed without any problem. The third assumption will be passed normally, because there is not a direct relation between flash setting and ordinary cement and spacer pumping. The second and fourth layers present a real obstacle for this assumption; if a flash setting takes place, pressure will follow flow rate behavior and cannot be stable or decrease during pumping. Then, the first assumption is eliminated.

The second assumption faces a contradiction with the first layer, during mechanical problem pressure reaction as bump not a progressive rise. There is no direct relation between mechanical problem and normal fluids pumping presented in layer three. The second assumption faces a real contradiction with layers two and four also, because mechanical problems do not give an adequate interpretation to down-hole lost or pumping with steady level, and pressure stable or decrease. Then, the second assumption is eliminated.

The third assumption passes through the first and third layers without any difficulties, because when false setting takes place, firstly, the separation of solids from fluids will take time and accordingly the pressure rises progressively; secondly, there is no relation with spacer reaching the open hole and the main problem, and at the contrary, cement pumped normally could be a sign of homogeneous cement which can be an indication of no setting of solids. On the other hand, the third assumption faces a real contradiction with the second and fourth layers, because in the case of false setting, if pumping is ongoing, either we will have return or pressure rise, especially in this situation where all cement was inside casing. Moreover, pressure rise to 2350 psi, and decrease after that even if pumping is still on going, this is far from the behavior of false setting. Then, the third assumption is eliminated.

The fourth assumption passes normally through the first layer, because when the formation closes, the annular pressure rises progressively and part of pressure will be bleeds off in the formation. The third layer does not present any problem, because there is no relation between formation and cement pumping schedule. The second and the fourth layers

Table 1 Well integrity system in terms of duration and operation

\begin{tabular}{|c|c|c|c|c|}
\hline \multirow[t]{2}{*}{ System } & \multicolumn{2}{|c|}{ In term of time } & \multicolumn{2}{|c|}{ In term of operation } \\
\hline & Short term & Long term & Principal & Secondary \\
\hline Drilling operation & $\mathrm{N}$ & $\mathrm{N}$ & $\mathrm{Y}$ & $\mathrm{Y}$ \\
\hline $\begin{array}{l}\text { Casing cement } \\
\text { operation }\end{array}$ & $\mathrm{Y}$ & $\mathrm{Y}$ & $\mathrm{Y}$ & $\mathrm{Y}$ \\
\hline $\begin{array}{l}\text { Drilling Fluids } \\
\text { system }\end{array}$ & $\mathrm{Y}$ & $\mathrm{N}$ & Y & Y \\
\hline Logging operation & $\mathrm{N}$ & $\mathrm{N}$ & $\mathrm{N}$ & $\mathrm{Y}$ \\
\hline Well head system & $\mathrm{Y}$ & $\mathrm{Y} / \mathrm{N}$ & $\mathrm{Y}$ & $\mathrm{N}$ \\
\hline BOP system & $\mathrm{Y}$ & $\mathrm{N}$ & $\mathrm{Y}$ & $\mathrm{N}$ \\
\hline Well control system & $\mathrm{Y}$ & $\mathrm{N}$ & $\mathrm{Y}$ & $\mathrm{Y}$ \\
\hline Completion system & $\mathrm{N}$ & $\mathrm{Y}$ & $\mathrm{Y}$ & $\mathrm{N}$ \\
\hline
\end{tabular}

$Y$ means yes; the system fulfills the desired requirements; $N$ means no, the system does not fulfill the desired requirements; $Y / N$ means situation of the well, production or abandonment 
enhance the assumption of formation restriction, because if it is the case, there will not have flow return and pressure rise progressively to reach formation frack limits, at this stage pressure will not increase.

Step 5 The real problem leading to pressure rise is the formation restriction due to an interaction with drilling or cementing fluids. It is highly recommended to study all possible reaction (contamination, fluid-geologic formation interaction, etc.) of fluids pumped down hole to avoid such undesirable problems, as shown in Appendix E.

Table 2 embodies the NPT engendered by the precedent incidents.

Table 3 represents the incidents.

\section{Conclusions}

Incidents' investigation represents the heart of procedure improvement and high-performance achievement. Each problem encloses lessons learned behind, which can avoid further incidents. Modified cheese model method points out the possibility to get the same result for numerous causes and directs the investigation toward the factual reason. Several case studies have been presented in this paper pointed out the merit of the method proposed.

Table 2 Nonproductive time due to flash setting

\begin{tabular}{lll}
\hline Well & Casing/liner & NPT generated (h) \\
\hline Well 4 & 133/8" CSG & 243 \\
Well 5 & 4 1/2 liner & 1809 \\
Well 6 & 13" 3/8 CSG & 291.75 \\
Well 7 & 13" 3/8 CSG & 973.5 \\
Well 8 & 9 " 5/8 CSG & 1300 \\
\hline
\end{tabular}

Open Access This article is licensed under a Creative Commons Attribution 4.0 International License, which permits use, sharing, adaptation, distribution and reproduction in any medium or format, as long as you give appropriate credit to the original author(s) and the source, provide a link to the Creative Commons licence, and indicate if changes were made. The images or other third party material in this article are included in the article's Creative Commons licence, unless indicated otherwise in a credit line to the material. If material is not included in the article's Creative Commons licence and your intended use is not permitted by statutory regulation or exceeds the permitted use, you will need to obtain permission directly from the copyright holder. To view a copy of this licence, visit http://creativecommons.org/licenses/by/4.0/.

\section{Appendix A}

\begin{tabular}{lc}
\hline Crew & Training \\
\hline Helper and beginner & Overview on cement operations, \\
& HSE, maintenance, software, \\
& techniques and job procedures \\
Cement operators and engineer & Cementing operations planning \\
field & and execution \\
Cement supervisor & Advanced cement operations (new \\
& technologies, HPHT, Geother- \\
Engineer & mal, etc.) \\
& Cement software advanced, \\
& cement job evaluation \\
\hline
\end{tabular}

\section{Appendix B}

Products checklist.
Table 3 HPABM-Cheese model easy presentation

\begin{tabular}{|c|c|c|c|}
\hline Well/analysis & Supposed problem (cause) & Phenomenon & The real problem \\
\hline Well 4 & $\begin{array}{l}\text { Flash setting } \\
\text { (rise of pressure) }\end{array}$ & $\begin{array}{l}\mathrm{KCl} \text { is } 25 \mathrm{~kg} \text { per sack } \\
\text { instead of } 50 \mathrm{~kg}\end{array}$ & Flash setting \\
\hline Well 5 & $\begin{array}{l}\text { Flash setting } \\
\text { (string stuck) }\end{array}$ & $\begin{array}{l}\text { Packer setting } \\
\text { Rotation of the string }\end{array}$ & Mechanical problem \\
\hline Well 6 & $\begin{array}{l}\text { Flash setting } \\
\text { (rise of pressure) }\end{array}$ & $\begin{array}{l}\text { Stay in static state } \\
\text { more than two hours }\end{array}$ & Logistic problem \\
\hline Well 7 & $\begin{array}{l}\text { Flash setting } \\
\text { (rise of pressure) }\end{array}$ & Poor mix water & Flash setting \\
\hline Well 8 & Flash setting (rise of pressure) & $\begin{array}{l}\text { Pressure remains at } 2300 \mathrm{psi} \\
\text { even if pumping is still } \\
\text { ongoing }\end{array}$ & Well formation restriction \\
\hline
\end{tabular}




\begin{tabular}{llll}
\hline $\begin{array}{l}\text { Products (unit lt, kg } \\
\text { or ton) }\end{array}$ & $\begin{array}{l}\text { Pro- } \\
\text { grammed } \\
\text { quantity }\end{array}$ & Real quantity & $\begin{array}{l}\text { Safety quantity } \\
\text { (real-pro- } \\
\text { grammed) }\end{array}$ \\
\hline
\end{tabular}

Cement class $\mathrm{G}$

(Blend)

Defoamer

Water

Surfactant

Weighting agent

Salt

Anti-settling

Fluid loss control

Retarder

Accelerator

Cement yield $\left(\mathrm{m}^{3} / \mathrm{T}\right)$

Mix water $\left(\mathrm{m}^{3} / \mathrm{T}\right)$

Total cement, ton

Total mix water, $\mathrm{m}^{3}$

Equipment and crew checklist.

\begin{tabular}{llll}
\hline Equipment & On location & On road & Not available \\
\hline
\end{tabular}

Cement crew

Cement unit

Cement head

Cement batch mixer

Piping system

Measurement system

Testing equipment

Hoper and mixer

Casing circulating head

Casing packer

Manifold system

\section{Appendix C}

\begin{tabular}{lll}
\hline Factor & Description & Remedial action \\
\hline $\begin{array}{l}\text { Displacement } \\
\text { volume }\end{array}$ & $\begin{array}{l}\text { Proportionality } \\
\text { between displace- } \\
\text { ment volume, } \\
\text { calculated based } \\
\text { on pump flow rate } \\
\text { and volume will }\end{array}$ & $\begin{array}{l}\text { If this factor is veri- } \\
\text { fied, then efficiency } \\
\text { of pumps will be } \\
\text { be found in reality } \\
\text { based on return at }\end{array}$ \\
& surface \\
\hline
\end{tabular}

\begin{tabular}{|c|c|c|}
\hline Factor & Description & Remedial action \\
\hline Pressure variations & $\begin{array}{l}\text { Proportionality } \\
\text { between the real } \\
\text { pressure and } \\
\text { simulated pres- } \\
\text { sure. If we cannot } \\
\text { use down-hole } \\
\text { circulation because } \\
\text { it subjected to } \\
\text { numerous influ- } \\
\text { ences (down-hole } \\
\text { conditions, float } \\
\text { equipment state, } \\
\text { hole geometry, } \\
\text { etc.), we oriented to } \\
\text { similar wells break } \\
\text { circulation, because } \\
\text { inside casing, the } \\
\text { conditions are } \\
\text { similar }\end{array}$ & $\begin{array}{l}\text { If this factor is veri- } \\
\text { fied, then leak of cir- } \\
\text { cuit will be judged }\end{array}$ \\
\hline $\begin{array}{l}\text { First bump and final } \\
\text { bump indication }\end{array}$ & $\begin{array}{l}\text { Proportionality } \\
\text { between pressure } \\
\text { and volume to } \\
\text { reach the first bump } \\
\text { and at the end of } \\
\text { displacement }\end{array}$ & $\begin{array}{l}\text { If this factor is veri- } \\
\text { fied, then propriety } \\
\text { of cement will be } \\
\text { verified }\end{array}$ \\
\hline
\end{tabular}

\section{Appendix D}

Post-cement failure factor (PCFF) deals with major problems that could be recognized while cementing, and the problems are presented in the table.

\begin{tabular}{llll}
\hline Problem & Description & PCFF & Remedial actions \\
\hline $\begin{array}{l}\text { Non-calibrated } \\
\text { hole }\end{array}$ & $\begin{array}{c}\text { This means } \\
\text { a problem }\end{array}$ & $(0-1)$ & $\begin{array}{c}\text { 1, Drilling with } \\
\text { adequate ROP }\end{array}$ \\
& while drilling, & 2, Drilling with \\
non-adequate & & adequate mud \\
density, lack in & \\
mud products, & \\
high ROP, etc.) & \\
If it is an under & \\
gage hole, a & \\
problem to run & \\
& casing or losses & \\
& while cementing \\
& may happen & \\
If there is a wash- & \\
& out, problem of \\
& cement job run- \\
& ning and quality \\
& may occur \\
\hline
\end{tabular}




\begin{tabular}{|c|c|c|c|}
\hline Problem & Description & PCFF & Remedial actions \\
\hline Losses persist & $\begin{array}{l}\text { The difference } \\
\text { between flow } \\
\text { in and out } \\
\text { confirms the } \\
\text { occurrence of } \\
\text { losses or no }\end{array}$ & $(0-1)$ & $\begin{array}{l}\text { 1, Pump LCM } \\
\text { 2, Pump cement } \\
\text { isolation plug }\end{array}$ \\
\hline $\begin{array}{l}\text { Abnormal down- } \\
\text { hole temperature }\end{array}$ & $\begin{array}{l}\text { Compared to } \\
\text { adjacent wells } \\
\text { or to the overall } \\
\text { behavior of } \\
\text { temperature } \\
\text { compared to } \\
\text { depth (Fig. 3) }\end{array}$ & $(0-1)$ & $\begin{array}{l}\text { 1, Confirm the log } \\
\text { temperature } \\
2, \text { Use safe tem- } \\
\text { perature, more } \\
\text { waiting is better } \\
\text { than flash setting }\end{array}$ \\
\hline Traces of gas & $\begin{array}{l}\text { Traces of gas } \\
\text { while drilling }\end{array}$ & $(0-1)$ & $\begin{array}{l}\text { 1, Confirm the use } \\
\text { of required mud } \\
\text { density } \\
\text { 2, Use gas stop } \\
\text { material }\end{array}$ \\
\hline $\begin{array}{l}\text { Mechanical } \\
\text { problem }\end{array}$ & $\begin{array}{l}\text { A mechanical } \\
\text { problem is } \\
\text { detected while } \\
\text { running casing } \\
\text { (Standoff) or } \\
\text { during testing } \\
\text { cement equip- } \\
\text { ment }\end{array}$ & $(0-1)$ & $\begin{array}{l}\text { 1, Fix any material } \\
\text { problem before } \\
\text { cementing }\end{array}$ \\
\hline Score & Cumulative score & $(0 \div 5)$ & $\begin{array}{l}\text { If cumulative score } \\
\text { is different from } \\
\text { " } 0 \text {," then there is } \\
\text { a risk }\end{array}$ \\
\hline
\end{tabular}

\section{Appendix E}

\begin{tabular}{|c|c|c|c|}
\hline Problem & Description & Cause & Remedial action \\
\hline \multirow[t]{2}{*}{$\begin{array}{l}\text { While running } \\
\text { casing }\end{array}$} & $\begin{array}{l}\text { Undesir- } \\
\text { able pres- } \\
\text { sure while } \\
\text { breaking } \\
\text { circulation, } \\
\text { compared to } \\
\text { simulation } \\
\text { (exploration } \\
\text { wells) or sim- } \\
\text { ulation and } \\
\text { nearby wells } \\
\text { (development } \\
\text { wells) }\end{array}$ & $\begin{array}{l}\text { Pieces of rigid } \\
\text { material } \\
\text { as steel or } \\
\text { rubber fall } \\
\text { inside casing }\end{array}$ & $\begin{array}{l}\text { If the column } \\
\text { is at surface, } \\
\text { then pull out } \\
\text { and unplug the } \\
\text { casing } \\
\text { If the column } \\
\text { is deeper } \\
\text { in the hole, } \\
\text { then continue } \\
\text { run in hole } \\
\text { and take in } \\
\text { consideration } \\
\text { the difference } \\
\text { of pressure } \\
\text { (compared to } \\
\text { FIT) while } \\
\text { cementing }\end{array}$ \\
\hline & $\begin{array}{l}\text { Bump of } \\
\text { pressure } \\
\text { during break } \\
\text { circulation, } \\
\text { no circulation } \\
\text { even after lot } \\
\text { of attempts }\end{array}$ & $\begin{array}{l}\text { Pieces of flex- } \\
\text { ible material } \\
\text { as cloths or } \\
\text { plastic fall } \\
\text { inside casing }\end{array}$ & $\begin{array}{l}\text { Pull out casing } \\
\text { to inspect } \\
\text { the situation. } \\
\text { Unplug inside } \\
\text { casing and } \\
\text { rerun column }\end{array}$ \\
\hline
\end{tabular}

\begin{tabular}{|c|c|c|c|}
\hline Problem & Description & Cause & Remedial action \\
\hline \multirow[t]{3}{*}{$\begin{array}{l}\text { While cement- } \\
\text { ing }\end{array}$} & $\begin{array}{l}\text { Under dis- } \\
\text { placement } \\
\text { of cement, } \\
\text { leading to } \\
\text { left cement } \\
\text { inside casing } \\
\text { and free pipe } \\
\text { in the upper } \\
\text { part of the } \\
\text { casing }\end{array}$ & $\begin{array}{l}\text { Rig pump } \\
\text { efficiency } \\
\text { problem }\end{array}$ & $\begin{array}{l}\text { Test pump effi- } \\
\text { ciency before } \\
\text { the beginning } \\
\text { of cement } \\
\text { operation } \\
\text { Use separate } \\
\text { displacement } \\
\text { tank } \\
\text { Confirm the } \\
\text { return volume }\end{array}$ \\
\hline & $\begin{array}{l}\text { Over displace- } \\
\text { ment of } \\
\text { cement, lead- } \\
\text { ing to shoe } \\
\text { track free of } \\
\text { cement and } \\
\text { free pipe in } \\
\text { the lower part } \\
\text { of casing }\end{array}$ & $\begin{array}{l}\text { Top plug dam- } \\
\text { aged } \\
\text { Rig pump } \\
\text { efficiency } \\
\text { non-accurate }\end{array}$ & $\begin{array}{l}\text { Inspection of } \\
\text { all cementing } \\
\text { equipment (top } \\
\text { plug) } \\
\text { Pump only } \\
\text { the required } \\
\text { volume of } \\
\text { displacement } \\
\text { Use separate } \\
\text { displacement } \\
\text { tank } \\
\text { Confirm the } \\
\text { return volume }\end{array}$ \\
\hline & $\begin{array}{l}\text { If any opera- } \\
\text { tional or } \\
\text { technical } \\
\text { problem } \\
\text { appears, } \\
\text { cement } \\
\text { equipment } \\
\text { down or } \\
\text { execution } \\
\text { difficulties, } \\
\text { reaction } \\
\text { must be at } \\
\text { time without } \\
\text { interruption } \\
\text { the smooth } \\
\text { running of } \\
\text { the job }\end{array}$ & $\begin{array}{l}\text { If cement stays } \\
\text { in static } \\
\text { state, gel will } \\
\text { start devel- } \\
\text { oped to reach } \\
\text { unpumpable } \\
\text { stage }\end{array}$ & $\begin{array}{l}\text { During cement } \\
\text { job, decisions } \\
\text { must be taken } \\
\text { as soon as pos- } \\
\text { sible, without } \\
\text { influencing the } \\
\text { hole cement } \\
\text { operation time }\end{array}$ \\
\hline \multirow[t]{2}{*}{$\begin{array}{l}\text { After cement- } \\
\text { ing recom- } \\
\text { mendations }\end{array}$} & $\begin{array}{l}\text { At the end } \\
\text { of cement } \\
\text { job test and } \\
\text { movement } \\
\text { cement } \\
\text { should be } \\
\text { done, while } \\
\text { cement was } \\
\text { in flexible } \\
\text { state }\end{array}$ & $\begin{array}{l}\text { If tests or } \\
\text { movement } \\
\text { will be done } \\
\text { later, when } \\
\text { compressive } \\
\text { strength was } \\
\text { developed, } \\
\text { cement } \\
\text { matrix will } \\
\text { be broken } \\
\text { and micro- } \\
\text { annulus will } \\
\text { be produced }\end{array}$ & $\begin{array}{l}\text { All pressure } \\
\text { tests or column } \\
\text { movement } \\
\text { must be done } \\
\text { during flexible } \\
\text { state of cement }\end{array}$ \\
\hline & $\begin{array}{l}\text { Cement evalu- } \\
\text { ation should } \\
\text { be done } \\
\text { after enough } \\
\text { time and via } \\
\text { adequate tool }\end{array}$ & $\begin{array}{l}\text { Due to } \\
\text { problem of } \\
\text { lightweight } \\
\text { cement and } \\
\text { compressive } \\
\text { strength }\end{array}$ & $\begin{array}{l}\text { Select log } \\
\text { adequate to } \\
\text { cement type } \\
\text { Wait on cement } \\
\text { in synchro- } \\
\text { nization of } \\
\text { other drilling } \\
\text { operation }\end{array}$ \\
\hline
\end{tabular}




\section{Appendix F}

\begin{tabular}{|c|c|c|c|c|}
\hline $\begin{array}{l}\text { Indica- } \\
\text { tor cat- } \\
\text { egory }\end{array}$ & $\begin{array}{l}\text { Indicator } \\
\text { abbreviation }\end{array}$ & Description & $\begin{array}{l}\text { Criteria of } \\
\text { evaluation } \\
\text { (binary system } \\
\text { only) }\end{array}$ & $\begin{array}{l}\text { Max } \\
\text { mark }\end{array}$ \\
\hline \multirow[t]{4}{*}{$\begin{array}{l}\text { Zero } \\
\text { KPI } \\
\text { factor }\end{array}$} & Flash set (FS) & $\begin{array}{l}\text { Sudden rise in } \\
\text { pressure due to } \\
\text { cement gel devel- } \\
\text { opment }\end{array}$ & 1 or 0 & 1 \\
\hline & $\begin{array}{l}\text { Cement left } \\
\text { inside cas- } \\
\text { ing (CLIC) } \\
\text { engen- } \\
\text { ders well } \\
\text { integrity } \\
\text { problem }\end{array}$ & $\begin{array}{l}\text { Due to wrong } \\
\text { calculation of } \\
\text { displacement, } \\
\text { there is a leak } \\
\text { somewhere in dis- } \\
\text { placement circuit, } \\
\text { plug problem or } \\
\text { equipment down }\end{array}$ & 1 or 0 & 1 \\
\hline & $\begin{array}{l}\text { Free pipe } \\
\text { which } \\
\text { requires } \\
\text { remedial } \\
\text { job }\end{array}$ & $\begin{array}{l}\text { Problem with com- } \\
\text { pressive strength } \\
\text { development } \\
\text { in some criti- } \\
\text { cal zones or all } \\
\text { annulus }\end{array}$ & 1 or 0 & 1 \\
\hline & $\begin{array}{l}\text { Problem with } \\
\text { service } \\
\text { company's } \\
\text { material, } \\
\text { staff or } \\
\text { software } \\
\text { leading to } \\
\text { interrupt } \\
\text { cement job }\end{array}$ & $\begin{array}{l}\text { Any problems } \\
\text { due to cement- } \\
\text { ing company } \\
\text { engender the total } \\
\text { loss of the drilling } \\
\text { objectives. (exam- } \\
\text { ple: } 1 \text {, cement } \\
\text { unit breakdown } \\
\text { for hours; } 2, \text { CSG } \\
\text { at bottom; 3, CSG } \\
\text { stuck; 4, fishing) }\end{array}$ & 1 or 0 & 1 \\
\hline \multirow[t]{5}{*}{$\begin{array}{l}\text { Princi- } \\
\text { pal }\end{array}$} & $\begin{array}{l}\text { HSE (acci- } \\
\text { dents with } \\
\text { at least one } \\
\text { day off) }\end{array}$ & $\begin{array}{l}\text { Accident during } \\
\text { cementing opera- } \\
\text { tion }\end{array}$ & $\begin{array}{l}\text { No acci- } \\
\text { dent }=20 ; \\
\text { accident } \\
\text { occurred }=0\end{array}$ & 20 \\
\hline & $\begin{array}{l}\text { BPL (behind } \\
\text { pipe losses) }\end{array}$ & $\begin{array}{l}\text { Lost classified as } \\
\text { seepage (less than } \\
3 \mathrm{~m}^{2} \text { ), partial lost } \\
\text { (more than } 3 \mathrm{~m}^{3} \\
\text { with returns) } \\
\text { or total lost (no } \\
\text { return) }\end{array}$ & $\begin{array}{l}\text { No losses }=10 ; \\
\text { seepage }=7 \\
\text { partial }=5 ; \\
\text { total }=0\end{array}$ & 10 \\
\hline & $\begin{array}{l}\text { GFB (Get } \\
\text { final bump) }\end{array}$ & $\begin{array}{l}\text { Pressure rises sud- } \\
\text { denly when top } \\
\text { plug reach the } \\
\text { float collar }\end{array}$ & $\begin{array}{l}\text { Get final } \\
\text { bump }=10 ; \text { no } \\
\text { final bump }=0\end{array}$ & 10 \\
\hline & $\begin{array}{l}\text { Cement } \\
\text { job as per } \\
\text { program } \\
\text { instructions }\end{array}$ & $\begin{array}{l}\text { Realization of } \\
\text { cement job should } \\
\text { be the mirror of } \\
\text { cement program }\end{array}$ & $\begin{array}{l}\text { Bad }=0 ; \\
\text { fair }=5 ; \\
\text { good }=10\end{array}$ & 10 \\
\hline & $\begin{array}{l}\text { Critical zone } \\
\text { isolation }\end{array}$ & $\begin{array}{l}\text { Example HB, } \\
\text { ALBIEN or any } \\
\text { trouble/week zone }\end{array}$ & $\begin{array}{l}\text { Critical zones } \\
\text { isolated = } 10 ; \\
\text { critical zones } \\
\text { aren't iso- } \\
\text { lated }=0\end{array}$ & 10 \\
\hline
\end{tabular}

\begin{tabular}{|c|c|c|c|c|}
\hline $\begin{array}{l}\text { Indica- } \\
\text { tor cat- } \\
\text { egory }\end{array}$ & $\begin{array}{l}\text { Indicator } \\
\text { abbreviation }\end{array}$ & Description & $\begin{array}{l}\text { Criteria of } \\
\text { evaluation } \\
\text { (binary system } \\
\text { only) }\end{array}$ & $\begin{array}{l}\text { Max } \\
\text { mark }\end{array}$ \\
\hline
\end{tabular}

\begin{tabular}{|c|c|c|c|c|}
\hline & $\begin{array}{c}\text { WOC (wait } \\
\text { on cement } \\
\text { hardness) }\end{array}$ & $\begin{array}{l}\text { Additional wait on } \\
\text { cement hardness } \\
\text { rather than the } \\
\text { one selected in } \\
\text { cement program }\end{array}$ & $\begin{array}{l}\text { No wait on } \\
\text { cement }=10 ; \\
\text { Wait on } \\
\text { cement less } \\
\text { than } 24 \mathrm{~h}=5 \text {; } \\
\text { Wait on } \\
\text { cement more } \\
\text { than } 24 \mathrm{~h}=0\end{array}$ & 10 \\
\hline & $\begin{array}{l}\text { Logging } \\
\text { evaluation } \\
\text { (Cement } \\
\text { quality) }\end{array}$ & $\begin{array}{l}\text { Related to } \mathrm{CBL} \text { or } \\
\text { equivalent; } \mathrm{CBL}< \\
15 \mathrm{mv}=\mathrm{Good} ; \\
15 \mathrm{mv}<\mathrm{CBL}< \\
40 \mathrm{mv}=\text { medium; } \\
40 \mathrm{mv}<\mathrm{CBL}= \\
\text { Poor to free pipe }\end{array}$ & $\begin{array}{l}\text { Good }=30 ; \\
\text { medium }=10 ; \\
\text { poor to free } \\
\text { pipe }=0\end{array}$ & 30 \\
\hline $\begin{array}{l}\text { Sec- } \\
\text { ond- } \\
\text { ary }\end{array}$ & $\begin{array}{l}\text { NPT (non- } \\
\text { productive } \\
\text { time) }\end{array}$ & $\begin{array}{l}\text { Nonproductive time } \\
\text { generated due to } \\
\text { cement failed }\end{array}$ & $\begin{array}{l}\text { No NPT gener- } \\
\text { ated }=20 ; \\
\text { less than } 24 \mathrm{~h} \\
\text { NPTs gener- } \\
\text { ated }=10 ; \\
\text { more than } \\
24 \text { h NPTs } \\
\text { generated }=0\end{array}$ & 20 \\
\hline
\end{tabular}

INT (intro- New technology or New technol- 10 ducing new other solutions ogy introtechnolo- introduced in duced $=10$; gies and cementing opera- no new techniques) tions in order to technology improve the qual- introduced $=0$ ity of cement

$\begin{array}{cccc}\begin{array}{c}\text { All equip- } \\ \text { ment and } \\ \text { staff are } \\ \text { ready at } \\ \text { time }\end{array} & \begin{array}{c}\text { All requirements } \\ \text { are conformed } \\ \text { and at time in } \\ \text { the rig }\end{array} & \begin{array}{c}\text { Yes }=30 ; \\ \text { almost } \\ \text { all }=20 ;\end{array} & 30 \\ \text { no }=0 & \\ \text { Sampling } & \begin{array}{l}\text { Samples should } \\ \text { be taken from } \\ \text { cement and mix } \\ \text { water }\end{array} & \begin{array}{c}\text { Yes }=10 ; \\ \text { No }=0\end{array} & 10 \\ & & \end{array}$

Pre-job safety Safety meeting held Yes $=10 ;$ no $=0 \quad 10$ meeting

HSE HSE rules break Yes $=0 ;$ no $=10 \quad 10$ standards (dumping conformity (cement) or spill (at surface), clean space after job, PPE, etc.)

Employees Problem with $\quad$ Yes $=0 ;$ no $=10 \quad 10$ competency laboratory test, and cement software, personprogram nel which influquality ence the cement program delivery 


\section{References}

Abdullah SA, Moaathe AA, Abrar AA, Salem HG (2019) Executing and monitoring cement job real time, SPE Oil and gas India conference and exhibition

Altabbakh H, Murray SL (2011) Applying the Swiss cheese model of accident causation, annual international conference of the American society for engineering management, Lubbock: Curran Associates, Inc., pp 301

Amin Rostomi S, Mirrajabi M, Stoian E, Babar K (2017) Managed pressure cementing in HPHT utilizing real time pressure estimation and control software - a case study. In: Offshore Technology conference, 1-4 May, Huston, Texas, USA

Bittleston SH, Ferguson J, Frigaard IA (2002) Mud removal and cement placement during primary cementing of an oil well. J Eng Math 43:229-253

Catalin T, Opeyemi B (2019) A review of cement testing apparatus and methods under $\mathrm{CO}_{2}$ environment and their impact on well integrity prediction—where do we stand? J Petrol Sci Eng 2019:116

Charles RC, Greg LC (1973) Mud displacement with cement slurries. J Petrol Technol 25(07):775-783

Choudhary HK, Anupama AV, Kumar R, Panzi ME, Matteppanavar S, Baburao NS, Sahoo B (2015) Observation of phase transformations in cement during hydration. Constr Build Mater 101:122-129

Dekker SWA (2002) Reconstructing human contributions to accidents: the new view on human error and performance. J Safety Res 33:371-385

Eduardo SS, Monica FN, Paulo RSM, Cristian RM, André LM, Gilson C (2004) Liquid displacement during cementing operations. Annu Trans Nordic Rheol Soc 12:93-100

Gauffinet-Garrault S (2012) The rheology of cement during setting. Woodhead Publ Ser Civ Struct Eng 2012:96-113

Griffith JE, Sabins FL, Harness PE (1992) Investigation of ultrasonic and sonic bond tools for detection of gas channels in cements. In: 67th Annual Technical conference and exhibition of the society of petroleum engineers Washington, DC

Guangping Z, Yongxue L, Guohua L, Yulu W (1999) Building of the petroleum drilling fluid engineering design expert system. J Cent South Univ Technol 6(1):37-40

Hanooman A (2008) Accident and incident investigation. In: SPE International Conference on health, safety, and environment in oil and gas exploration and production

Ikpeka PM, Odo JE, Benedict UW, Utojiuba ID (2019) Effects of Additive concentrations on cement rheology at different temperature conditions. Int J Eng Works 6(03):50-70

Javed IB (1987) Thermal monitoring of flash setting in portland cement clinkers. Thermochim Acta 199:235-241

Navas L, Bermudez R, Saleh MG, AlKatheeri YS, ElHassan A, Kapoor S, Jain B, Pallapothu S, Shakour SA, Sinha RK (2016) Challenges and solutions while cementing long extended reach wells in UAE, Abu Dhabi International Petroleum Exhibition \& Conference, 7-10 November, Abu Dhabi, UAE

Reason J (1990) Human error. Cambridge University Press, New York

Smith TR, Ravi KM (1991) Investigation of drilling fluid properties to maximize cement displacement efficiency. In: 66th Annual Technical Conference and Exhibition of the Society of Petroleum Engineers held in Dallas, TX

Thomas JJ, James S, Ortego JA, Musso S, Auzerais F(2012) Fundamental investigation of the chemical and mechanical properties of high-temperature-cured oilwell cements, Offshore Technology Conference, 30 April-3 May, Houston, Texas, USA

Zichang L, Julie MV, Donald JJ, Anthony TI (2018) A newly developed wellbore-simulation apparatus to study performance of oilwell cement. SPE Drill Complet 33:2

Publisher's Note Springer Nature remains neutral with regard to jurisdictional claims in published maps and institutional affiliations. 